\title{
ANALISIS KERENTANAN TANAMAN TERHADAP ANCAMAN KEKERINGAN PERTANIAN MENGGUNAKAN PENDEKATAN MULTI-TEMPORAL DI DAS PROGO HULU
}

\author{
Oleh: \\ Wahyu Widiyatmoko', Sudibyakto², Emilya Nurjani² \\ ${ }^{1}$ Program Studi Pendidikan Geografi FKIP UMS \\ 2Fakultas Geografi UGM \\ wahyu.widiyatmoko@ums.ac.id
}

\begin{abstract}
Abstrak
DAS Progo Hulu merupakan kawasan pertanian penting yang ada di Kabupaten Temanggung. Defisit curah hujan yang cukup panjang berdampak pada aktivitas pertanian di daerah ini. Tujuan dari penelitian ini adalah untuk menganalisis tingkat kerentanan tanaman secara multi-temporal di DAS Progo Hulu Kabupaten Temanggung. Metode yang digunakan adalah menganalisis data curah hujan, menghitung selisih NDVI pada setiap tempo 16 hari, dan melakukan validasi objek tanaman pertanian. Hasil penelitian menunjukkan Kerentanan kekeringan pertanian yang dideteksi menggunakan selisih NDVI menunjukkan bahwa lereng dan kaki vulkan Sindoro dan Sumbing memiliki kerentanan paling tinggi. Hal tersebut disebabkan karena daerah tersebut memiliki jenis tanaman semusim yang tidak tahan terhadap cengkaman air.
\end{abstract}

Kata Kunci: kerentanan tanaman, kekeringan pertanian, analisis multi-temporal

\begin{abstract}
Upper Progo Watershed is an important agricultural area in Temanggung Regency. Long precipitation deficit give impacts to the agricultural activities. The research aims at analyzing the vulnerability level of plants in the research area by using a multi-temporal analysis. The methods employed in this research include analyzing the rainfall data, calculating the different NDVI value within a tempo of 16 days, and validating the plants. This research shows that the vulnerability of agricultural drought detected using NDVI defference indicates that the slope and foot of Sindoro and Sumbing volcano show the highest vulnerability level. This happens because those areas are planted with seasonal crops that can't grow in water stress condition.
\end{abstract}

Keywords: plant vulnerability, agricultural drought, multi-temporal analysis

\section{PENDAHULUAN}

Air merupakan salah satu komponen kehidupan yang sangat penting bagi kelangsungan makhluk hidup. Air akan selalu tersedia pada suatu wilayah karena adanya suatu siklus hidrologi. Salah satu tahapan dalam siklus hidrologi adalah presipitasi. Presipitasi menjadi sumber air utama yang mensuplai air di sebuah catchment area (DAS) pada daerah tropis. Berkurangnya jumlah presipitasi akan mengakibatkan berkurangnya jumlah cadangan air di daratan dalam bentuk lengas tanah, aliran permukaan, dan airtanah. Hal ini akan mengakibatkan kekeringan pada suatu wilayah. Kekeringan terjadi pada semua zona iklim baik pada daerah dengan curah hujan tinggi maupun rendah yang berhubungan 
Analisis Kerentanan Tanaman Terhadap Ancaman Kekeringan Pertanian Menggunakan Pendekatan Multi-Temporal Di DAS Progo Hulu

dengan berkurangnya jumlah presipitasi yang diterima selama periode waktu tertentu, seperti dalam satu musim atau satu tahun (Mishra dan Singh, 2010).

Kekeringan adalah jenis bahaya komplek yang disebabkan karena terganggunya keseimbangan air dan berdampak pada pertanian, ekologi, dan sosial ekonomi (Du dkk., 2013). Kekeringan pertanian adalah salah satu jenis kekeringan selain kekeringan meteorologis, hidrologi, dan sosial-ekonomi. Kekeringan pertanian berhubungan dengan berkurangnya kandungan air dalam tanah (lengas tanah) sehingga tidak mampu lagi memenuhi kebutuhan air bagi tanaman pada suatu periode tertentu. Kekeringan ini terjadi setelah terjadinya gejala kekeringan meteorologis (Adiningsih, 2014). Jika tidak ditangani dengan baik, maka kekeringan pertanian akan menyebabkan kekeringan hidrologi dan sosial-ekonomi.

Kerentanan didefinisikan sebagai derajat kehilangan pada sebuah elemen berisiko atau sekumpulan elemen sebagai hasil risiko dari kejadian sebuah peristiwa alam pada magnitudo tertentu dan digambarkan pada skala 0 (tidak rusak) hingga 1 (rusak total) (UNDRO, 1991). Kerentanan kekeringan adalah terbatasnya kemampuan dari suatu sistem untuk mengatasi kekeringan dan ditentukan oleh kekuatan dan ketahanannya terhadap kekurangan air. Kerentanan kekeringan dapat berupa indeks dari ketidakmampuan suatu komunitas atau ekosistem untuk mengatasi kekeringan (Vicente dkk., 2012).

Kerentanan kekeringan pertanian terutama terjadi pada tanaman yang terkena dampak dari defisit lengas tanah. Kekeringan dapat terjadi pada sembarang fase pertumbuhan tanaman dan dapat diklasifikasikan dalam kekeringan masa awal tanam berdampak pada penggantian tanaman, kekeringan periodik selama pertumbuhan tanaman, dan kekeringan masa akhir pertumbuhan tanaman (Jongdee dkk., 1997). Pengurangan dampak dan risiko bencana kekeringan dapat dilakukan dengan cara mengurangi kerentanan disamping mitigasi bencana, pencegahan, dan bantuan pemerintah (Cheng dan Tao, 2010). Tujuan dari penaksiran kerentanan adalah untuk identifikasi aksi yang tepat yang dapat mengurangi kerentanan sebelum potensial kerusakan benar-benar terjadi (Wilhelmi dan Wilhite, 2002).

Nilai kerentanan menunjukkan seberapa besar dampak apabila suatu elemen beresiko berinteraksi dengan defisit lengas tanah. Mishra dan Singh (2011) mengungkapkan bahwa dampak dari kekeringan tergantung pada beberapa faktor yaitu tingkat keparahan, frekuensi, area, dan durasi yang secara esensial mengarah pada analisis spasio-temporal atau dengan kata lain adalah analisis kekeringan wilayah. Teknologi berdasarkan informasi geospasial telah tersedia untuk menentukan risiko dan kerentanan dari suatu ekosistem. Informasi geospasial dapat digunakan untuk pemantauan kekeringan, peringatan dini, dan penaksiran dampak kekeringan berdasarkan informasi realtime untuk mendukung proses pengambilan keputusan (Vicente dkk., 2012).

Mudah tidaknya daun tanaman layu dapat menjadi indikator kerentanan kekeringan pertanian. Daun yang layu pada tanaman adalah peristiwa yang samar-samar. Kesamarsamaran yang besar akan terjadi pada permulaan kekeringan daripada akhir kekeringan. Kelayuan daun akan berkembang secara gradual kemudian dengan waktu singkat akan 
kembali normal ketika kekeringan berakhir. Daun yang layu dapat diidentifikasi dari selisih nilai NDVI selama periode tertentu (Rulinda dkk., 2012).

Musim kemarau 2015 mendorong Pemerintah Kabupaten Temanggung menetapkan darurat kekeringan berdasarkan surat keputusan Bupati Temanggung nomor 337 tahun 2015 tentang darurat kekeringan selama 90 hari yang ditetapkan sejak 1 Agustus 2015 ("Temanggung Dinyatakan Darurat Kekeringan - Tribunnews," 2015). Dasar penetapan darurat kekeringan ini dikarenakan banyak desa yang mengalami kekeringan, akibatnya banyak warga yang kekurangan air bersih dan lahan pertanian tidak bisa diolah ("Temanggung Darurat Kekeringan - Suara Merdeka," 2015).

DAS Progo hulu merupakan bagian dari DAS Progo yang sebagian besar wilayahnya terletak di Kabupaten Temanggung, Jawa Tengah. Penelitian ini bertujuan untuk menganalisis kerentanan tanaman yang terdapat di wilayah DAS Progo Hulu dengan menggunakan pendekatan multi-temporal dengan memanfaatkan citra Landsat 8 .

\section{METODE}

Metode penelitian yang digunakan dalam penelitian ini dibagi kedalam tiga tahap agar tujuan penelitian tercapai, yaitu:

\section{Analisis Kekeringan Meteorologi Tahun 2015}

Durasi defisit curah hujan dianalisis dengan menggunakan grafik imbangan air antara curah hujan bulanan dan laju evapotranspirasi yang dihitung menggunakan rumus Thornwaite. Kekeringan akan dimulai jika nilai evapotranspirasi lebih tinggi dari jumlah curah hujan dan akan berakhir jika presipitasi bisa melebihi nilai evapotranspirasi.

\section{Analisis Kerentanan Kekeringan Pertanian}

Analisis kerentanan kekeringan pertanian dengan cara mengidentifikasi kelayuan daun yang ada pada tanaman. Kelayuan daun pada tanaman dapat diidentifikasi menggunakan selisih nilai NDVI, yaitu NDVI akhir dikurangi NDVI awal. Perhitungan indeks NDVI dilakukan dengan memanfaatkan citra Landsat 8 OLI yang memiliki resolusi temporal 16 hari. Penentuan indeks NDVI diperoleh dengan menggunakan persamaan sebagai berikut:

$$
\text { NDVI }=(\text { NIR }- \text { Red }) /(N I R+\text { Red })
$$

\section{Pengambilan Sampel Validasi Objek}

Pengambilan sampel untuk validasi objek penginderaan jauh menggunakan teknik purposive sampling. Sampel yang akan dijadikan sampel untuk validasi interpretasi citra sudah ditentukan dahulu posisinya sebelum melakukan cek lapangan. Jumlah sampel untuk validasi objek tergantung pada kebutuhan interpretasI.

\section{HASIL DAN PEMBAHASAN}

\section{Kekeringan Meteorologi di DAS Progo Hulu Tahun 2015}

Grafik imbangan air dibuat dengan membandingkan jumlah curah hujan dengan jumlah evaporasi. Hasil perhitungan evaporasi potensial dengan menggunakan metode Thornwaite. Hasil perhitungan menunjukkan bahwa jumlah evaporasi potensial berkisar 
Analisis Kerentanan Tanaman Terhadap Ancaman Kekeringan Pertanian Menggunakan Pendekatan Multi-Temporal Di DAS Progo Hulu

pada angka $130 \mathrm{~mm}$. Permulaan kekeringan meteorologis di DAS Progo hulu terbagi menjadi 2 bagian, yaitu 5 stasiun hujan mendeteksi permulaan kekeringan meteorologis terjadi pada bulan Mei dan 3 stasiun hujan yang mendeteksi kekeringan meteorologis pada bulan Juni. Permulaan dan akhir dari kekeringan meteorologis digunakan sebagai dasar untuk memulai analisis citra Landsat 8 untuk mendeteksi defisit lengas tanah sebagai indikator terjadinya kekeringan pertanian di DAS Progo hulu. Landsat 8 memiliki resolusi temporal 16 hari sehingga analisis kekeringan pertanian dilakukan setiap 16 hari selama bulan Mei - November 2015.

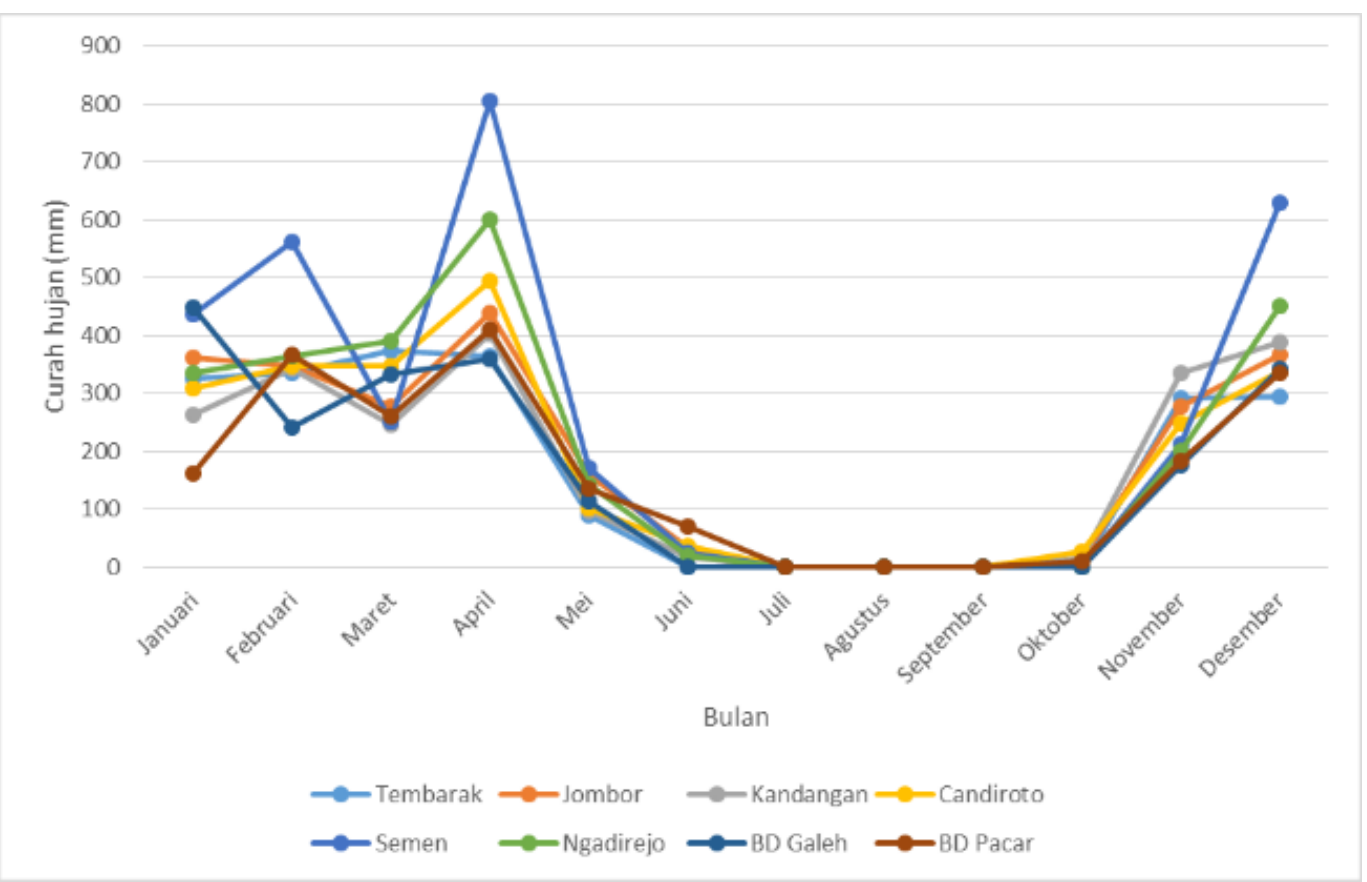

Gambar 1. Grafik curah hujan bulanan 8 stasiun hujan di DAS Progo hulu Tahun 2015. (Sumber: Hasil analisis data curah hujan Dinas PU Temanggung 2016)

\section{Kerentanan Kekeringan Pertanian di DAS Progo Hulu}

Kerentanan kekeringan pertanian dalam penelitian ini adalah kerentanan tanaman terhadap cengkaman air. Mudah tidaknya tanaman layu jika terjadi pengurangan lengas dalam tanah akan mempengaruhi tingkat kerentanan tanaman saat terjadi kekeringan. Mudah tidaknya tanaman layu dapat diidentifikasi menggunakan metode selisih NDVI dan analisis multi-temporal. Tanaman yang memiliki kerentanan tinggi (mudah layu) saat terjadi kekeringan akan memiliki defisit selisih NDVI yang besar, sebaliknya tanaman yang memiliki kemampuan bertahan terhadap cengkaman air, nilai NDVI akan lebih stabil.

Penggunaan metode selisih NDVI memiliki kelebihan untuk mendeteksi kerentanan tanaman secara spasial-temporal dan sesuai kondisi nyata dilapangan. Penelitian ini menggunakan dua analisis selisih NDVI untuk mengetahui tingkat pengurangan nilai NDVI dari waktu ke waktu. Analisis pertama menggunakan selisih dua tanggal perekaman yang berurutan. Analisis ini menghasilkan tren kecepatan pengurangan nilai NDVI pada setiap 
tanggal perekaman. Hasil rata-rata selisih NDVI dengan menggunakan citra dengan dua tanggal perekaman berurutan ditampilkan pada Gambar 2.

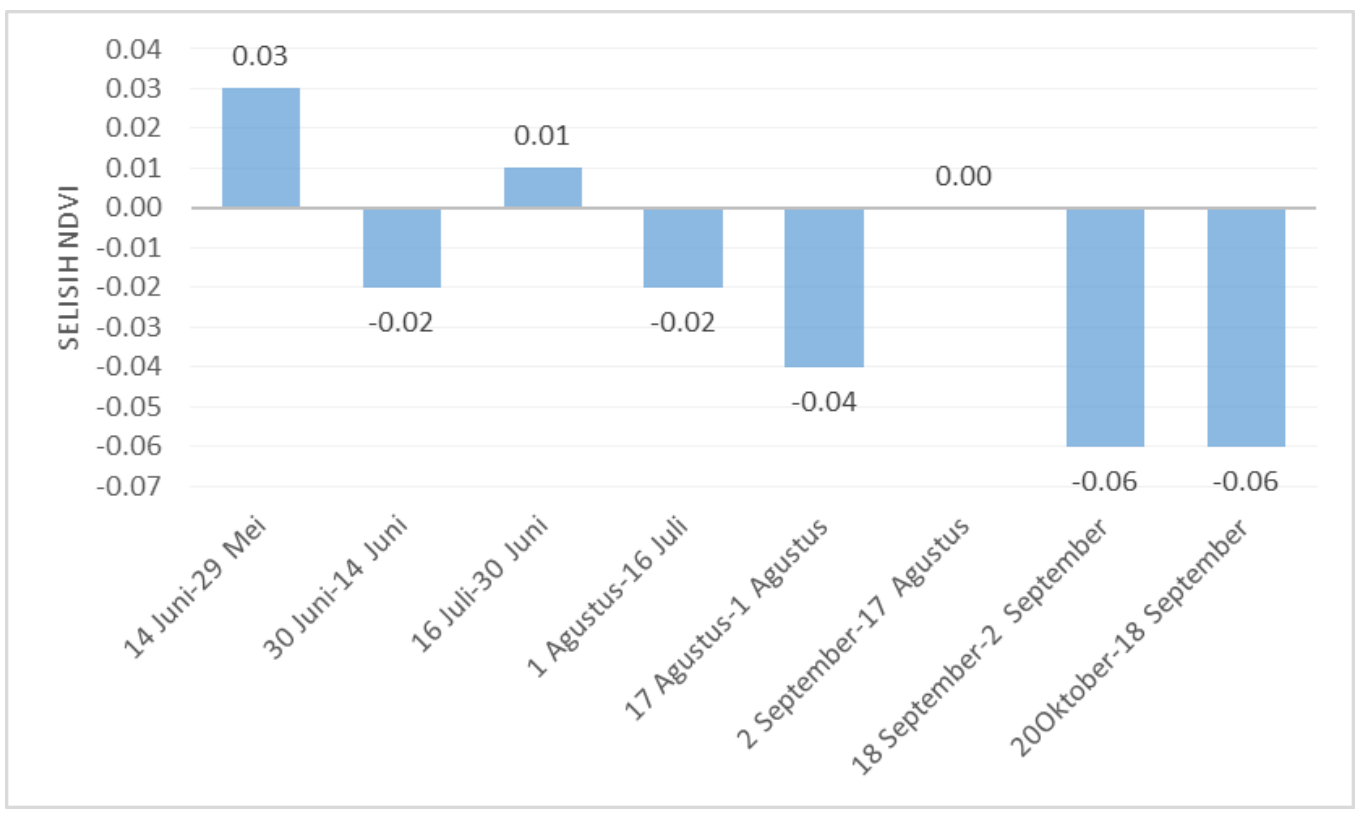

Gambar 2 Rata-Rata Selisih NDVI pada Tanggal Perekaman Berurutan di DAS Progo Hulu 2015. (Sumber: Analisis Citra Landsat 8 2016)

Gambar 2 menunjukkan bahwa selisih NDVI bernilai positif mengindikasikan bahwa tanggal perekaman setelahnya lebih hijau daripada tanggal perekaman sebelumnya. Sebaliknya jika nilai selisih NDVI bernilai negatif terjadi pengurangan kehijauan pada citra dengan tanggal perekaman setelahnya. Grafik menunjukkan peningkatan kehijauan pada citra tanggal 14 Juni dan 16 Juli 2015, selain kedua tanggal tersebut selisih NDVI bernilai negatif dan nol. Banyaknya tanggal yang bernilai negatif memberikan informasi bahwa kehijauan di daerah penelitian terus berkurang seiring dengan minimnya presipitasi. Penurunan kehijauan paling besar terjadi dari tanggal 2 September ke 18 September 2015.

Analisis kedua menggunakan salah satu tanggal perekaman citra sebagai acuan. Penelitian ini menggunakan tanggal 16 Juli 2015 sebagai acuan untuk menghitung selisih NDVI dari tanggal perekaman yang lain. Tanggal 16 Juli dipilih karena persentase awan yang sangat kecil dan tanggal ini masih berada pada masa awal kekeringan meteorologi. Analisis kedua menghasilkan besarnya selisih NDVI pada setiap tanggal perekaman terhadap tanggal acuan. Besarnya selisih NDVI dapat menunjukkan besarnya penurunan NDVI pada kurun waktu tertentu (masa kekeringan). Besarnya penurunan NDVI pada setiap tanggal perekaman terhadap tanggan acuan dapat dilihat pada Gambar 3. 


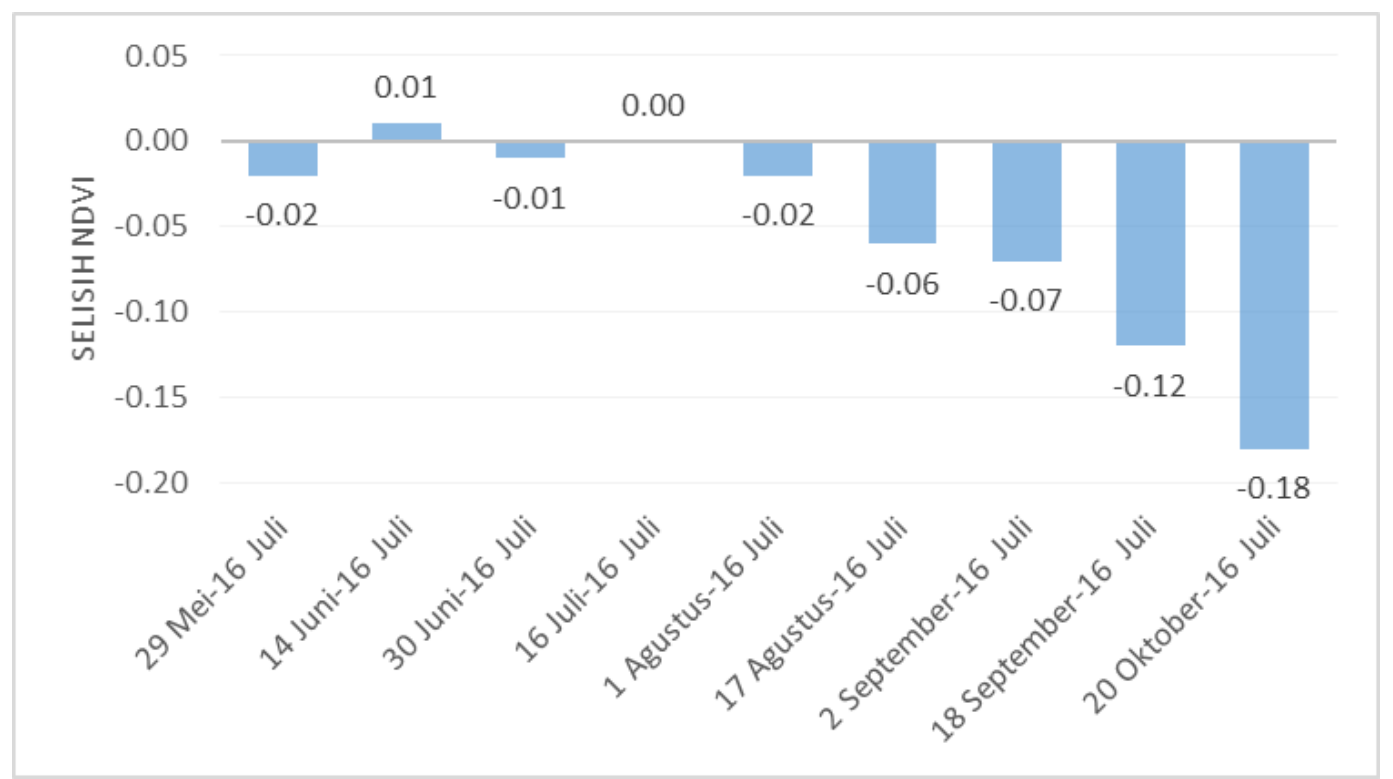

Gambar 3. Rata-Rata Selisih NDVI terhadap Citra Tanggal Perekaman 16 Juli di DAS Progo Hulu Tahun 2015 (Sumber: Analisis Citra Landsat 8 2016)

Gambar 3 menunjukkan bahwa grafik kehijauan mengalami kenaikan sedikit pada masa awal kekeringan meteorologi kemudian terus mengalami penurunan karena tidak adanya presipitasi. Penurunan kehijauan menunjukkan kandungan klorofil yang terus berkurang yang dapat disebabkan tanaman kekurangan air karena tidak ada lengas tanah yang dapat diserap oleh akar. Penurunan nilai NDVI juga dapat mengindikasikan semakin tingginya kerentanan tanaman terhadap kekeringan. Grafik menunjukkan bahwa semakin curam gradien garis menunjukkan penurunan nilai NDVI yang cukup besar. Citra tanggal 18 September dan 20 Oktober menunjukkan garis yang cukup curam pada grafik. Persebaran mengenai kecepatan penurunan NDVI di daerah penelelitian disajikan dalam Gambar 4.

Peta selisih NDVI yang disajikan pada Gambar 4 dibagi menjadi 5 kelas selisih NDVI berdasarkan pembagian kelas dengan metode Natural Breaks pada selisih NDVI 18 September 2015 dan 16 Juli 2015. Pembagian kelas selisih NDVI secara rinci dapat dilihat pada Tabel 1. Gambar 4 menunjukkan bahwa beberapa bagian di daerah penelitian mengalami perubahan warna yang tidak sama. Warna biru tua menunjukkan kenaikan nilai NDVI terhadap nilai NDVI 16 Juli 2015 dan warna coklat tua menunjukkan penurunan nilai NDVI paling signifikan terhadap nilai NDVI tanggal 16 Juli 2015. 

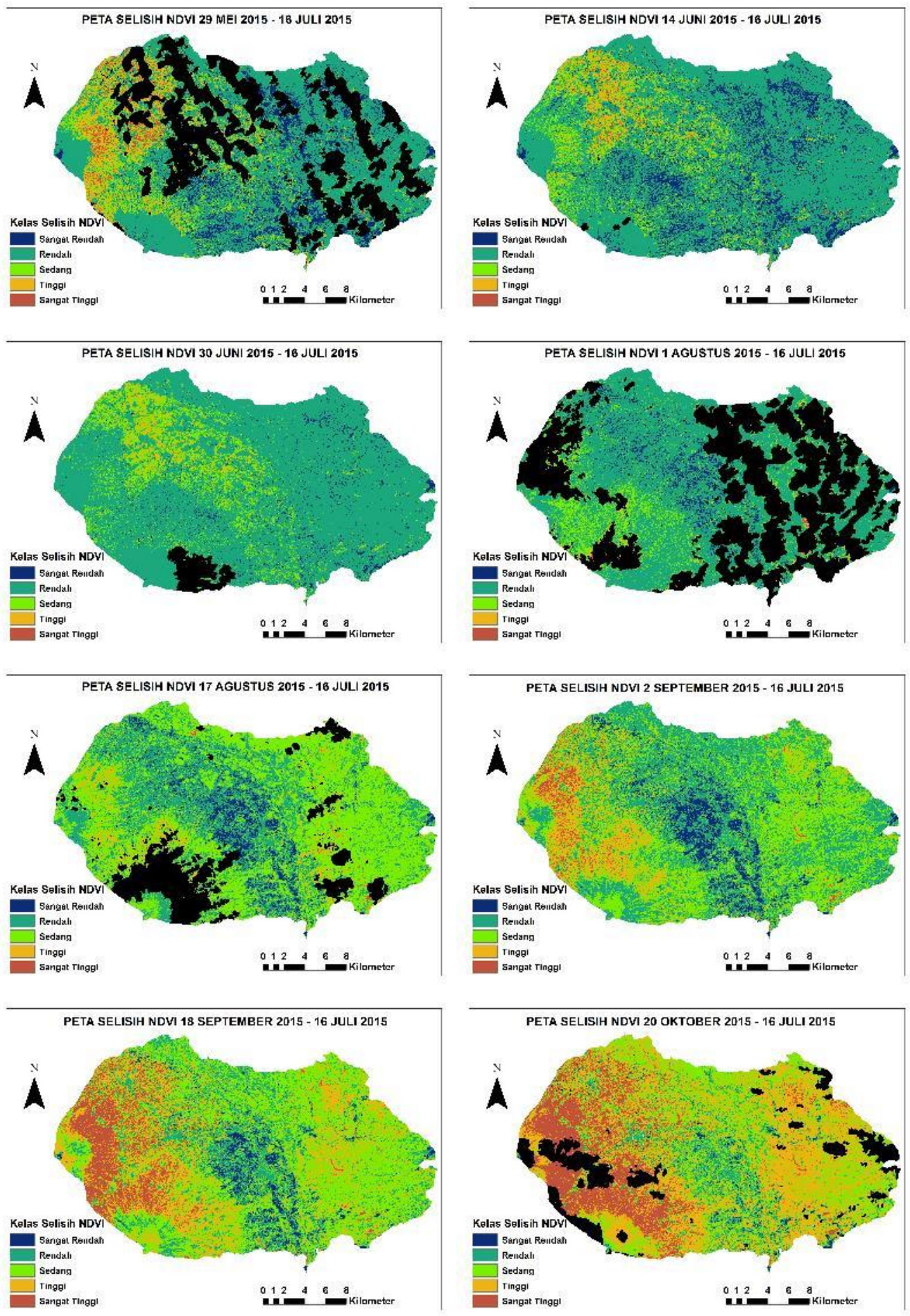

Gambar 4 Peta Selisih NDVI dengan Acuan Citra Tanggal 16 Juli di DAS Progo Hulu 2015 (Sumber: Analisis Citra Landsat 8 2016)

Gambar 4 menunjukkan warna biru tua hampir menyebar secara merata di daerah penelitian hingga tanggal 1 Agustus 2015. Persebaran warna biru tua yang merata 
Analisis Kerentanan Tanaman Terhadap Ancaman Kekeringan Pertanian Menggunakan Pendekatan Multi-Temporal Di DAS Progo Hulu

menunjukkan pertambahan jumlah klorofil pada tanaman. Hal ini mengindikasikan bahwa pada daerah tersebut tanaman belum terpengaruh oleh defisit curah hujan yang terjadi sejak bulan Mei 2015. Tanaman masih mampu menyerap air dari tanah untuk kelangsungan hidupnya secara normal dan untuk pertumbuhan tanaman. Perubahan warna biru tua menjadi hijau mulai terjadi pada tanggal 17 Agustus 2015. Pada tanggal ini pertumbuhan tanaman mulai terganggu dengan indikasi pengurangan jumlah klorofil. Tanaman mulai kekurangan suplai air dari tanah karena defisit curah hujan. Dominasi warna biru tua terletak di bagian tengah daerah penelitian. Bagian ini merupakan dataran kaki gunung api Sindoro dengan lereng landai dan jaringan irigasi yang baik. Daerah ini masih dapat suplai air dari jaringan irigasi walaupun terjadi defisit curah hujan.

Tabel 1 Pembagian kelas selisih NDVI di DAS Progo Hulu

\begin{tabular}{ccc}
\hline No & Nilai Selisih NDVI & Kelas Selisih NDVI \\
\hline 1 & $<-0,274803$ & Sangat Tinggi \\
2 & $-0,274803--0,151071$ & Tinggi \\
3 & $-0,151071--0,059616$ & Sedang \\
4 & $-0,059616-0,080255$ & Rendah \\
5 & $>0,080255$ & Sangat Rendah \\
\hline
\end{tabular}

(Sumber: Pembagian kelas selisih NDVI 18 September 2015 dengan 16 Juli 2015 metode Natural Breaks)

Warna coklat tua mulai muncul pada tanggal 2 September 2015 pada lereng vulkan Sindoro dan sebagain kecil di lereng vulkan Sumbing. Daerah ini mengalami penurunan nilai NDVI yang lebih cepat dibanding wilayah lain pada daerah penelitian. Warna coklat tua mengindikasikan penurunan klorofil yang cukup signifikan dan termasuk dalam kelas kerentanan sangat tinggi. Warna coklat tua, coklat muda, dan hijau terus meluas hingga tanggal 20 Oktober 2015 dan menyisakan sebagian kecil daerah berwarna biru tua dibagian tengah daerah penelitian. Warna coklat tua dan coklat muda meluas secara signifikan pada tanggal 20 Oktober 2015 terutama pada bagian vulkan Sindoro dan Sumbing dan bagian timur daerah penelitian. Hal ini menunjukkan bahwa banyak tanaman yang mengalami pengurangan klorofil secara signifikan karena pada tanggal ini defisit curah hujan sudah berlangsung lama yang mengakibatkan suplai air untuk tanaman didalam tanah sudah menurun secara drastis. Tanaman mengalami layu atau bahkan kematian karena sudah tidak mendapat suplai air.

Peta kerentanan untuk keperluan penaksiran risiko kekeringan pertanian dibuat dengan menghitung selisih NDVI antara citra tanggal 18 September 2015 dan 16 Juli 2015. Citra tanggal 16 Juli 2015 mewakili masa awal defisit curah hujan dan citra tanggal 18 September 2015 mewakili defisit curah hujan yang sudah berlangsung cukup lama. Kedua citra pada tanggal tersebut dipilih dikarenakan tidak adanya gangguan awan sehingga infomasi selisih NDVI dapat dilihat secara utuh untuk keseluruhan daerah penelitian.

Peta selisih kedua tanggal tersebut kemudian dibuat rasio persentase. Pembuatan persentase penurunan NDVI dilakukan untuk memudahkan dalam pembacaan skala pada peta kerentanan. Persentase penurunan NDVI pada peta kerentanan dibuat dengan 
membandingkan selisih NDVI dengan nilai NDVI tanggal acuan awal. Perbandingan antara selisih NDVI dan tanggal perekaman acuan (16 Juli 2015) kemudian dibuat persentase dan dibagi ke dalam 5 kelas. Pembagian kelas persentase penurunan menggunakan metode kuantil yang terdapat pada software ArcGIS 10.1. Pembagian kelas persentase penurunan NDVI di DAS Progo Hulu disajikan pada Tabel 2. Peta kelas kerentanan kekeringan pertanian dari hasil konversi nilai selisih NDVI menjadi persentase penurunan nilai NDVI di daerah penelitian dapat dilihat pada Gambar 5.

Tabel 2 Pembagian kelas kerentanan kekeringan pertanian di DAS Progo Hulu berdasarkan persentase penurunan NDVI

\begin{tabular}{cccc}
\hline No & $\begin{array}{c}\text { Persentase Penurunan } \\
\text { NDVI }\end{array}$ & Kelas Kerentanan & Skor Kelas Kerentanan \\
\hline 1 & $>33,3 \%$ & Sangat Tinggi & 5 \\
2 & $21,6 \%-33,3 \%$ & Tinggi & 4 \\
3 & $14,5 \%-21,6 \%$ & Sedang & 3 \\
4 & $8,2 \%-14,5 \%$ & Rendah & 2 \\
5 & $<8,2 \%$ & Sangat Rendah & 1 \\
\hline
\end{tabular}

(Sumber: Pembagian kelas persentase penurunan NDVI 18 September 2015 dengan 16 Juli 2015 metode Kuantil)

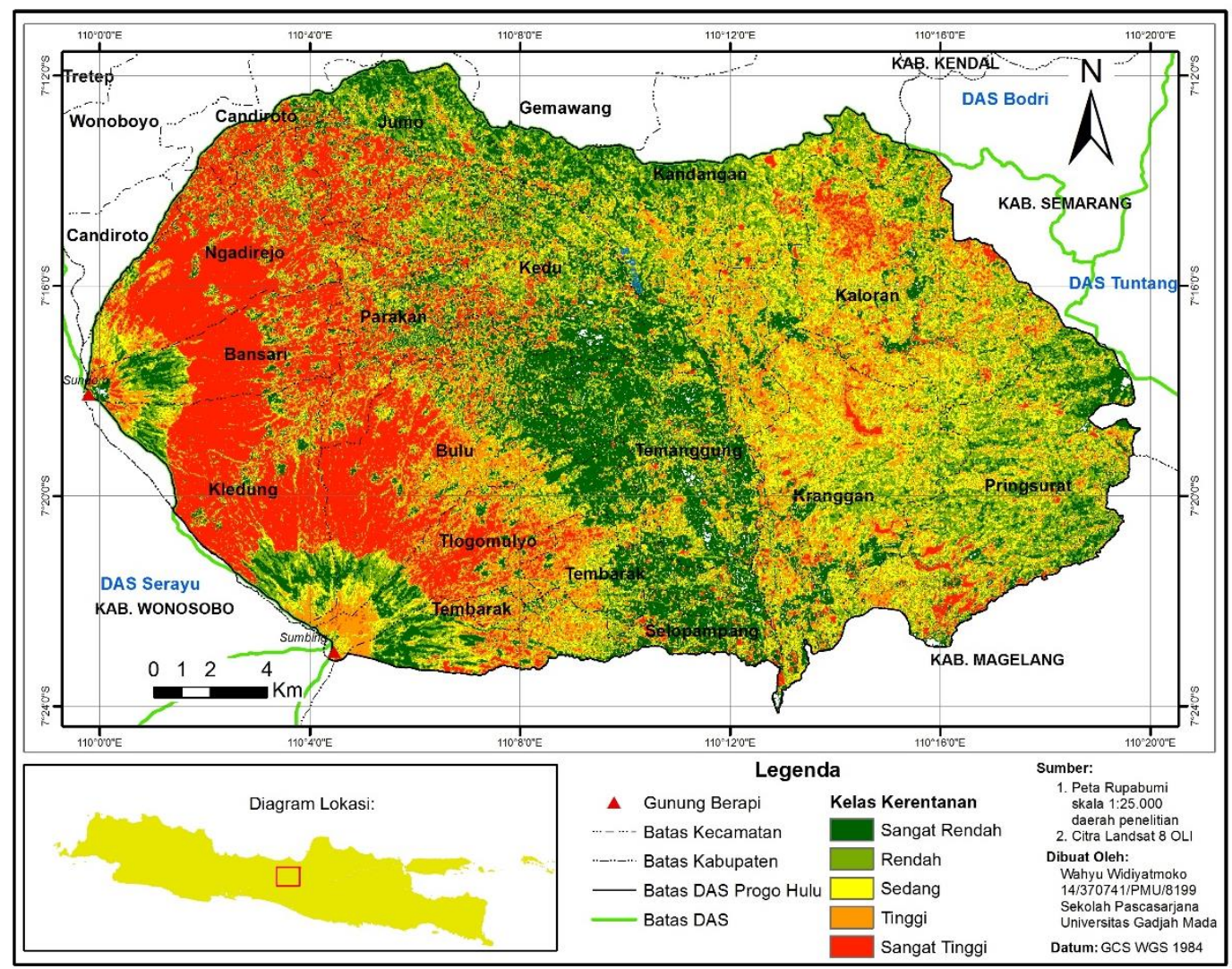

Gambar 5. Peta kerentanan kekeringan pertanian DAS Progo Hulu (Sumber: Analisis Citra Landsat 8 OLI 2016) 
Analisis Kerentanan Tanaman Terhadap Ancaman Kekeringan Pertanian Menggunakan Pendekatan Multi-Temporal Di DAS

Gambar 5 menunjukkan bahwa kelas kerentanan sangat tinggi ditunjukkan dengan warna merah yang mendominasi bagian barat daerah penelitian yang berupa lereng vulkan Sindoro dan Sumbing. Tingginya tingkat kerentanan di daerah ini terjadi karena tanaman tidak mampu menyerap air dari dalam tanah karena memiliki akar yang pendek. Tingkat kerentanan tinggi biasanya terjadi pada tanaman semusim dimana akar tanaman hanya mampu menjangkau lapisan tanah atas. Kerentanan tinggi yang dicerminkan dengan penurunan nilai NDVI yang tinggi juga tidak hanya terjadi pada tanaman semusim saja. Penurunan secara signifikan juga terjadi pada tanaman keras karena lamanya hari defisit curah hujan. Tanaman keras yang rata-rata memiliki nilai NDVI yang cukup tinggi karena memiliki daun yang lebat tidak mampu mempertahankan daunnya. Tanaman harus mempertahankan hidupnya dalam keadaan defisit air. Tanaman harus mengurangi proses penguapan (transpirasi) dengan cara menggugurkan daunnya. Banyaknya daun yang berguguran menyebabkan nilai NDVI turun secara signifikan, sehingga daerah ini juga memiliki kerentanan kekeringan yang tinggi.

Kelas kerentanan dibagi menjadi 5 kelas dengan luasannya masing-masing. Luasan kelas kerentanan di DAS Progo Hulu disajikan dengan grafik pada Gambar 6.

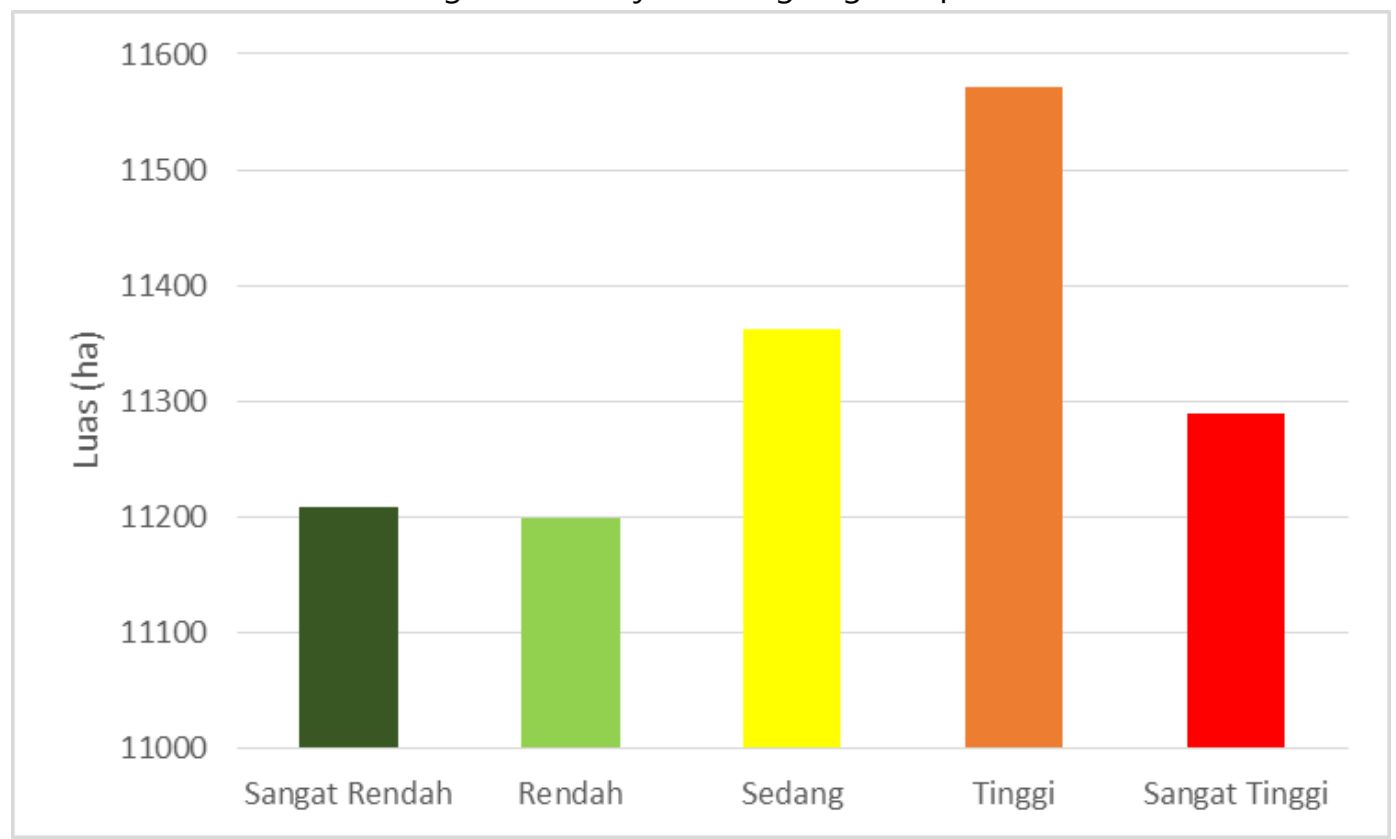

Gambar 6 Luasan kelas kerentanan kekeringan pertanian di DAS Progo Hulu (Sumber: Analisis data 2016)

Gambar 6 menunjukkan bahwa setiap kelas kerentanan memiliki luasan yang hampir sama. Kelas kerentanan tinggi merupakan luasan yang paling tinggi diantara kelas kerentanan yang lain. Pembagian kelas kerentanan dibuat dengan menggunakan metode kuantil. Metode ini menghasilkan panjang kelas dengan nilai tertentu dan menghasilkan pembagian luas menurut kelas kerentanan menghasilkan luasan setiap kelas kerentanan yang hampir sama. 
Hasil analisis jenis tanaman yang dilakukan berdasarkan hasil lapangan pada setiap kelas kerentanan. Hasil tersebut menunjukkan hal yang cukup unik terjadi pada jenis tanaman tembakau. Tembakau memiliki kelas kerentanan yang berbeda-beda tergantung lokasi tanaman. Tembakau merupakan tanaman favorit yang ditanam luas oleh petani setiap musim kemarau tiba. Masa tanam tembakau biasanya dilakukan setiap bulan April Mei kemudian pemanenan sekitar bulan Agustus - September. Daerah sentra tanaman tembakau adalah berada di lereng vulkan Sindoro dan Sumbing, akan tetapi daerah yang memiliki elevasi lebih rendah yang berada di bagian tengah daerah penelitian juga sering ditanami tembakau.

Daerah lereng vulkan yang hanya mengandalkan air hujan memiliki masa tanam tembakau lebih awal daripada daerah tengah yang memiliki sistem irigasi lebih baik. Masa tanam yang lebih awal yang menyebabkan kenaikan NDVI disekitar lereng dan kaki vulkan Hal ini ditunjukkan pada perubahan warna dari coklat-kuning pada tanggal perekaman 29 Mei 2015 menjadi biru untuk beberapa waktu hingga tanggal perekaman 1 Agustus 2015 (Gambar 4). Penurunan NDVI pada lereng dan kaki vulkan mulai terjadi pada tanggal 17 Agustus 2015 yang mengindikasikan bahwa tembakau sudah mulai dipanen.

Daerah bagian tengah daerah penelitian memiliki masa tanam tembakau yang lebih lambat daripada daerah vulkan di bagian barat. Keterlambatan penanaman tembakau disebabkan karena daerah ini memiliki sistem irigasi yang lebih baik sehingga suplai air tercukupi lebih lama setelah terjadi defisit curah hujan. Adanya suplai air menyebabkan petani lebih memilih tanaman lain seperti padi. Tanaman tembakau ditanam setelah petani merasa suplai air benar-benar kurang, sehingga tanaman tembakau ditanam lebih lambat dari pada daerah barat. Tanaman tembakau yang tumbuh menghasilkan kenaikan NDVI yang menyebabkan peta pada Gambar 4 berwarna biru. Pertumbuhan tembakau inilah yang menyebabkan wilayah tengah daerah penelitian memiliki warna biru tua saat wilayah lain mengalami penurunan nilai NDVI yang cukup signifikan. Fenomena tanaman tembakau yang memiliki variasi kelas kerentanan sangat besar yaitu dari kelas kerentanan sangat tinggi hingga sangat rendah menunjukkan bahwa bukan hanya jenis tanaman yang menyebabkan kerentanan pertanian, akan tetapi masa tanam dan suplai air sangat berpengaruh terhadap nilai selisih NDVI.

Hal yang berbeda terjadi di bagian timur daerah penelitian. Daerah timur daerah penelitian merupakan daerah perkebunan yang didominasi oleh tanaman keras. Kelas kerentanan bervariasi dan menyebar secara spasial. Daerah ini terdapat daerah dengan tingkat kerentanan sangat tinggi. Tingkat kerentanan sangat tinggi memiliki jenis tanaman sengon dan bagian bawah ditanami palawija, seperti jagung, ketela, dan cabai. Tanaman palawija tidak tahan terhadap kekeringan karena memiliki akar yang pendek sehingga saat terjadi kekeringan tanaman ini tidak mampu bertahan dan mengalami penurunan NDVI yang cukup signifikan.

Perkebunan kopi mendominasi bagian timur daerah penelitian. Tanaman kopi seringkali diselingi tanaman sengon, mahoni, kelapa atau tanaman keras lain. Pada peta kelas kerentanan, perkebunan kopi memiliki kelas kerentanan rendah hingga sedang. Penurunan NDVI yang tinggi disebabkan karena tanaman keras memiliki nilai NDVI awal 
Analisis Kerentanan Tanaman Terhadap Ancaman Kekeringan Pertanian Menggunakan Pendekatan Multi-Temporal Di DAS Progo Hulu

yang tinggi juga. Penurunan persentase NDVI menunjukkan bahwa banyaknya tanaman yang layu yang ada di perkebunan kopi.

Tanaman padi juga ditanam dibeberapa tempat di daerah penelitian. Padi merupakan tanaman yang membutuhkan banyak air pada masa awal pertumbuhannya. Hasil lapangan menunjukkan bahwa tanaman padi mempunyai tingkat kerentanan sedang hingga sangat tinggi. Hutan pinus juga merupakan tanaman yang ada di lereng atas vulkan dekat dengan kerucut vulkan. Tanaman pinus memiliki kerentanan rendah hingga sangat rendah. Hal ini menunjukkan bahwa tanaman pinus mengalami penurunan NDVI tidak terlalu signifikan. Nilai NDVI yang tinggi pada pinus juga memiliki aspek bahaya lain jika keadaan lengas tanah bernilai sangat rendah. Keadaaan kering dengan bahan bakar yang banyak (seresah, ranting, dan kayu) menyebabkan daerah ini menglami rawan kebakaran hutan jika musim kemarau panjang datang.

\section{SIMPULAN}

Kerentanan kekeringan pertanian yang dideteksi menggunakan selisih NDVI menunjukkan bahwa lereng dan kaki vulkan Sindoro dan Sumbing memiliki kerentanan paling tinggi. Hal tersebut disebabkan karena daerah tersebut memiliki jenis tanaman semusim yang tidak tahan terhadap cengkaman air.

\section{UCAPAN TERIMA KASIH}

Tulisan ini merupakan bagian dari penelitian tugas akhir tesis yang berjudul "Analisis Perambatan Defisit Lengas Tanah Secara Spasio-Temporal untuk Penaksiran Risiko Kekeringan Pertanian di DAS Progo Hulu" di Program Studi S2 Ilmu Lingkungan Minat GeoInformasi untuk Manajemen Bencana UGM. Penulis mengucapkan terima kasih kepada berbagai pihak yang telah membantu dalam proses penelitian, terutama kepada tim survei lapangan, saudara Sentot Catur P., S.Pd, Hermawan Kuswantoko., S.Pd. dan Aziz Fahmi Hertami., S.Pd., serta terima kasih kepada Kementerian Pendidikan dan Kebudayaan melalui Program Beasiswa Unggulan yang telah membantu penulis secara finansial dalam menyelesaikan studi S-2 di Universitas Gadjah Mada.

\section{DAFTAR PUSTAKA}

Adiningsih, E. S. 2014. Tinjauan Metode Deteksi Parameter Kekeringan Berbasis Data Penginderaan Jauh (pp. 210-220). Seminar Nasional Penginderaan Jauh.

Cheng, J., and Tao, J. 2010. Fuzzy Comprehensive Evaluation of Drought Vulnerability Based on the Analytic Hierarchy Process. Agriculture and Agricultural Science Procedia, 1 , 126-135.

Du, L., Tian, Q., Yu, T., Meng, Q., Jancso, T., Udvardy, P., and Huang, Y. 2013. A comprehensive drought monitoring method integrating MODIS and TRMM data. International Journal of Applied Earth Observation and Geoinformation, 23 (1), 245-253.

Jongdee, S., Mitchell, J. H., and Fukai, S. 1997. Modelling approach for estimation of rice yield reduction due to drought in Thailand. In Breeding strategies for rainfed lowland rice in drought-prone environments (pp. 65-73). Ubon Ratchathani: Australian Centre for International Agricultural Research.

Mishra, A. K., \& Singh, V. P. 2010. A review of drought concepts. Journal of Hydrology, 
391(1-2), 202-216. 2

Mishra, A. K., \& Singh, V. P. 2011. Drought modeling - A review. Journal of Hydrology, 403(1-2), 157-175.

Rulinda, C. M., Dilo, a., Bijker, W., and Stein, a. 2012. Characterising and quantifying vegetative drought in East Africa using fuzzy modelling and NDVI data. Journal of Arid Environments, 78, 169-178.

Temanggung Darurat Kekeringan - Suara Merdeka. 2015. Retrieved September 16, 2015, from http://berita.suaramerdeka.com/smcetak/temanggung-darurat-kekeringan/

Temanggung Dinyatakan Darurat Kekeringan - Tribunnews. 2015. Retrieved September 16, 2015, from http://www.tribunnews.com/regional/2015/08/01/-temanggungdinyatakan-darurat-kekeringan

UNDRO. 1991. Mitigating Natural Disasters: Phenomena, Effects and Options: A Manual for Policy makers and Planners. New York: United Nation.

Wilhelmi, O. V., and Wilhite, D. A. 2002. Assessing Vulnerability to Agricultural Drought: A Nebraska Case Study. Natural Hazard, 25, 37-58. 